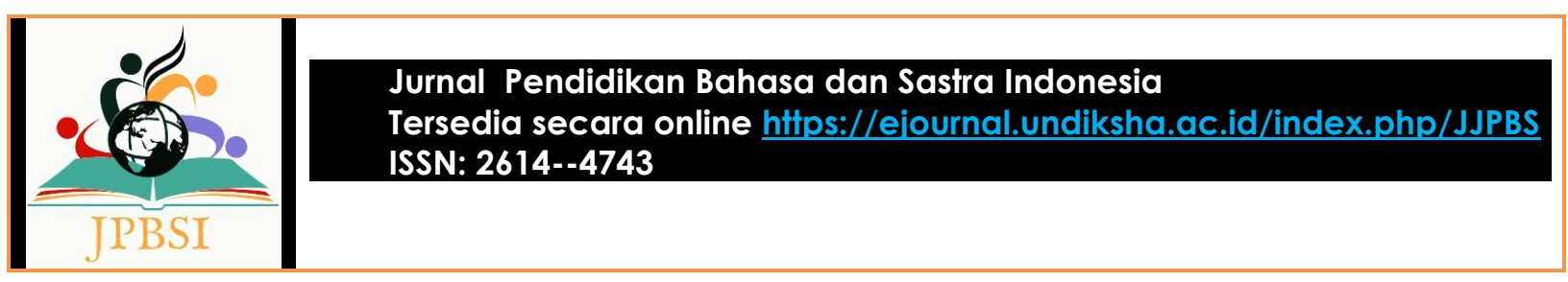

\title{
DEKONSTRUKSI MASKULINITAS MAINSTREAM DALAM NOVEL THE NAME OF THE GAME KARYA ADELINA AYU
}

\author{
Zulfikar Alamsyah ${ }^{1}$, Muhamad Adji ${ }^{2}$, Mochamad Irfan Hidayatullah ${ }^{3}$ \\ ${ }_{1,2,3}$ Program Studi Magister Ilmu Sastra, Fakultas Ilmu Budaya, Universitas Padjadjaran \\ Sumedang, Jawa Barat, Indonesia
}

Surel:zulfikar20001@mail.unpad.ac.id ${ }^{1}$, m.adji@unpad.ac.id², hidayatullahirfan@gmail.com³

\begin{tabular}{|c|c|}
\hline \multicolumn{2}{|r|}{ Abstrak } \\
\hline $\begin{array}{l}\text { Kata Kunci: } \\
\text { Dekonstruksi; } \\
\text { Maskulinitas } \\
\text { Mainstream; Novel; } \\
\text { Teenlit. }\end{array}$ & $\begin{array}{l}\text { Tujuan dari penelitian ini adalah untuk mendekonstruksi maskulinitas mainstream } \\
\text { tersebut yang terdapat di dalam novel The Name of The Game karya Adelina Ayu. } \\
\text { Penelitian ini menggunakan teori dan metode dekonstruksi Derida yakni teori yang } \\
\text { membahas oposisi biner yang akan menimbulkan gagasan baru di dalam sebuah karya } \\
\text { sastra. Teknik pengumpulan data yang digunakan adalah teknik membaca dan mencatat } \\
\text { untuk mendapatkan hasil mengenai dekonstruksi maskulinitas mainstream dalam novel } \\
\text { The Name of The Game karya Adelina Ayu. Hasil dari penelitian ini menunjukkan } \\
\text { bahwa tokoh Zio menghadirkan maskulinitas baru yang menggabungkan sisi feminin } \\
\text { dengan sisi maskulin yang seimbang. Ada tiga aspek dalam maskulinitas baru yang Zio } \\
\text { tampilkan yakni laki-laki yang merawat diri, bebas berekspresi, dan laki-laki yang } \\
\text { lemah lembut. Kesimpulannya adalah ketiga aspek maskulinitas baru yang ditampilkan } \\
\text { oleh tokoh Zio lewat pribadinya menciptakan maskulinitas yang memadupadankan } \\
\text { antara sifat maskulin dan feminin yang seimbang. Lewat kepribadiannya yang unik, Zio } \\
\text { menunjukkan bahwasanya laki-laki tidak harus selalu kaku, urakan, dan agresif. Namun } \\
\text { laki-laki juga bisa tampil lebih modis, ekspresif, dan penuh kasih sayang saat } \\
\text { berinteraksi dengan orang-orang di sekitarnya. }\end{array}$ \\
\hline \multicolumn{2}{|r|}{ Abstract } \\
\hline $\begin{array}{l}\text { Keywords: } \\
\text { Deconstruction; } \\
\text { Mainstream } \\
\text { Masculinity; Novel; } \\
\text { Teenlit }\end{array}$ & $\begin{array}{l}\text { The purpose of this study is to deconstruct the mainstream masculinity described in the } \\
\text { novel The Name of The Game by Adelina Ayu. This study uses Derida's theory and } \\
\text { method of deconstruction, that is a theory that discusses binary oppositions that will } \\
\text { give rise to new ideas in a literary work. Data collection techniques used are reading } \\
\text { and note-taking techniques to obtain results regarding the deconstruction of } \\
\text { mainstream masculinity in Adelina Ayu's novel The Name of The Game. The results of } \\
\text { this study indicate that the character named Zio presents a new masculinity that } \\
\text { combines the feminine side with the masculine side in a balanced way. There are three } \\
\text { aspects of Zio's new masculinity, that is men who take care of themselves, free } \\
\text { expression, and men who are gentle. The conclusion is that the three new aspects of } \\
\text { masculinity displayed by Zio's character through his personality create a masculinity } \\
\text { that combines masculine and feminine traits that are balanced. Through his unique } \\
\text { personality, Zio shows that men don't always have to be rigid, sloppy, and aggressive. } \\
\text { But men can also appear more fashionable, expressive, and affectionate when } \\
\text { interacting with the people around them. }\end{array}$ \\
\hline $\begin{array}{l}\text { Diterima/direview/ } \\
\text { dipublikasi }\end{array}$ & 21 Juni 2021/ 30 Juni 2021/ 30 September 2021 \\
\hline
\end{tabular}

PENDAHULUAN

Gender merupakan sebuah istilah yang sering disalahartikan oleh masyarakat umum. Barlas (2007) pernah menyebutkan bahwa kesalahpahaman yang dialami oleh masyarakat mengenai gender ini diakibatkan karena adanya pemahaman dalam masyarakat bahwa konsep gender itu sama dengan konsep seks, padahal keduanya merupakan konsep yang berbeda. Gender adalah sebuah konstruksi 


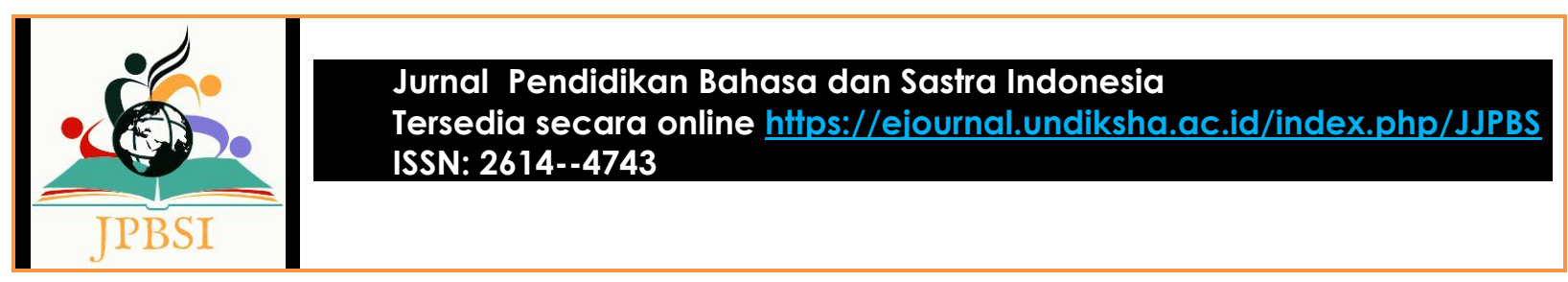

sosial yang diciptakan oleh masyarakat yang menghasilkan perbedaan fungsi, peran, status, dan tanggung jawab antara laki-laki dan perempuan. Gender itu memiliki sifat yang cair dan bisa dipertukarkan karena gender bukanlah bersifat kodrati yang diturunkan atau diberikan sejak manusia lahir.

Pembahasan mengenai gender tidak akan pernah jauh dari dua istilah yakni maskulin dan feminin. Dalam pandangan heteronormativitas, maskulin selalu dikaitkan dengan sifat atau karakter yang harus dimiliki oleh seorang pria, dan feminin adalah sifat-sifat atau karakteristik yang harus dimiliki oleh seorang perempuan. Pandangan heteronormativitas yang membagi gender dalam perspektif oposisi biner ini membuat konsep gender yang cair dan bisa dipertukarkan akan sulit untuk diterima. Hal inilah yang terjadi di Indonesia. Pada umumnya masyarakat Indonesia selalu mengklasifikasikan gender berdasarkan jenis kelamin yakni laki-laki dan perempuan, juga mendasarkannya pada peran dan ekspresi gender pada dua jenis kelamin itu saja. Tatanan heteronormatif ini lebih singkatnya mengharuskan laki-laki dan perempuan untuk tunduk pada aturan heteroseksualitas.

Seperti halnya budaya masyarakat Indonesia yang memandang laki-laki sebagai sorang pribadi yang kuat. Laki-laki harus bisa melakukan segala sesuatu dengan pekerjaan yang menguras tenaga. Laki-laki harus tampil macho dan dilarang melakukan aktivitas yang feminin seperti halnya merawat diri. Dalam budaya masyarakat Indonesia, seorang laki-laki haruslah menunjukkan dirinya dengan sifat maskulin yang mainstream. Berkaitan dengan maskulinitas mainstream, David dan Brannon (1976) menyebutkan bahwa terdapat empat elemen yang harus dimiliki seorang pria. Keempat elemen tersebut adalah no sissy stuff, be a big wheel, be a sturdy oak, dan give em hell.

No sissy stuff adalah elemen pertama yang harus dilakukan oleh setiap laki-laki. Para lelaki dilarang untuk bersinggungan secara langsung dengan hal-hal feminin yang biasa dilakukan oleh perempuan (Dermatoto, 2010). Hal-hal yang dimaksud di sini adalah barang-barang yang sering digunakan oleh perempuan seperti make up, barang-barang yang lucu dengan warna merah muda yang mendominasi, dll. Selain barang-barang yang sering digunakan oleh perempuan, seorang laki-laki juga tidak boleh melakukan kegiatan-kegiatan yang dianggap feminin seperti senang berbelanja, memasak, bergosip, dll. Elemen kedua yang harus dimiliki seorang lelaki adalah be a big wheel. Yang dimaksud dari elemen kedua ini maskulinitas dapat diukur dari kesuksesan, kekuasaan, dan mendapaykan pengaguman dari orang-orang yang ada di sekitarnya (Prameswari, 2014). Selain itu laki-laki harus memiliki kekayaan, ketenaran, dan status yang sangat lelaki. Seorang lelaki bukan hanya harus merepresentasikan dirinya sebagai lelaki yang macho tetapi juga ia harus mendapatkan pengakuan dari orang lain bahwa dirinya memang sangat maskulin.

Elemen ketiga adalah be a sturdy oak. Seperti layaknya pohon ek yang kuat, laki-laki juga harus menjadi seorang pribadi yang kuat. Kelelakian membutuhkan rasionalitas, kekuatan, dan kemandirian. Seorang lelaki harus tetap bertindak secara tenang dalam berbagai situasi, tidak menunjukkan emosi, dan tidak menunjukkan kelemahannya (Prameswari, 2014). Elemen yang terakhir adalah give em hell. Hal ini berkaitan dengan sifat berani yang harus ditunjukkan oleh seorang pria (Pratami \& Hasiholan, 2020). Laki-laki harus mampu mengambil resiko walaupun alasan dan rasa takut menginginkan sebaliknya. Elemen ini berkaitan dengan posisi laki-laki dalam struktur sosial masyarakat. Laki-laki yang menjadi seorang pemimpin harus bisa menjadi pelindung bagi anggotanya.

Keempat elemen yang disebutkan oleh David dan Brannon itu telah megkontruksi maskulinitas mainstream di dalam kehidupan masyarakat. Dalam kehiduan sosial, apabila seorang lelaki tidak menampilkan sifat-sifat maskulin seperti itu maka mereka akan dianggap gagal. Berpenampilan lemah, emosional, atau berlaku inefisien secara seksual merupakan suatu ancaman utama terhadap kepercayaan diri seorang laki-laki. Sifat-sifat maskulinitas mainstream yang disebutkan tadi juga tidak hanya berlaku di dunia nyata. Banyak sekali media-media yang menghadirkan sosok lelaki dengan sifat 


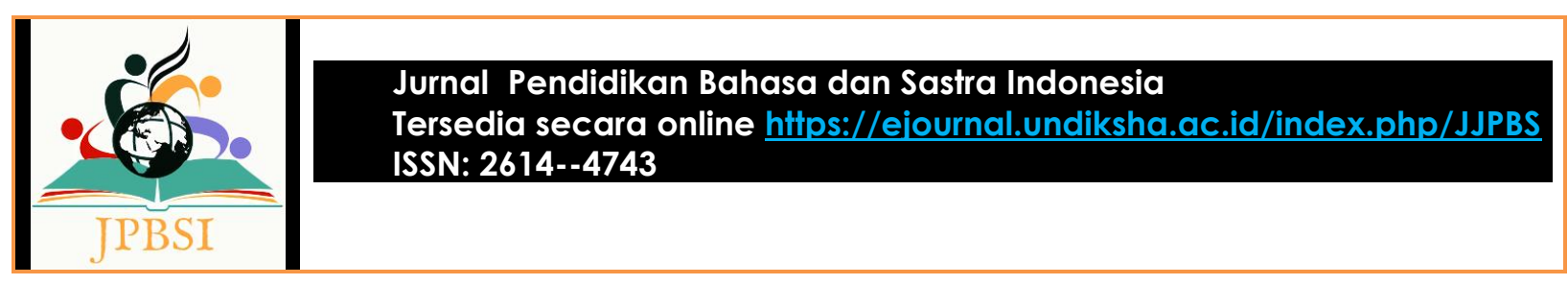

maskulinitas yang mainstream. Seperti dalam ranah sastra, tokoh laki-laki kerap kali ditampilkan sesuai dengan maskulinitas mainstream tersebut. Contohnya dalam karya sastra populer Indonesia, kebanyakan karya-karya sastra populer Indonesia sering menampilkan tokoh laki-laki macho yang senang berkelahi dan tampil urakan. Sebut saja cotohnya seperti tokoh Roy dalam novel Balada si Roy karya Gol A Gong atau di tahun 2000-an terkenal pula tokoh Dilan lewat tulisan Pidi Baiq yang juga ditampilkan sebagai anak geng motor yang senang berkelahi. Kedua tokoh tersebut menampilkan maskulinitas mainstream dalam dirinya. Roy dan Dilan jarang atau bahkan tidak pernah bersinggungan dengan hal yang feminin, mereka juga ditampilkan sebagai seorang laki-laki yang agresif dan kuat. Menunjukkan bahwa dirinya tidak terkalahkan dan mendapatkan pengakuan dari tokoh lainnya bahwa mereka adalah sosok laki-laki yang tahan banting.

Namun seiring berkembangnya zaman, karakteristik sastra populer yang menghadirkan tokoh dengan penampilan gender yang sesuai dengan jenis kelaminnya mulai bergeser sedikit demi sedikit. Saat ini mulai hadir penulis-penulis yang mengisahkan tentang laki-laki ataupun perempuan yang tampil dengan karakteristik gender yang berbeda dengan jenis kelaminnya. Novel The Name of The Game karya Adelina Ayu merupakan salah satu sastra populer Indonesia yang menghadirkan tokohnya dengan karakteristik yang bertolak belakang dengan heteronormativitas. Novel yang awalnya ditulis oleh Ayu dalam aplikasi wattpad ini mengisahkan tentang percintaan dan persahabatan di antara tokoh Zio, Flo, dan Daryll. Zio sebagai salah satu tokoh utama dalam novel ini merupakan seorang laki-laki yang memiliki perilaku menyimpang dari nilai maskulinitas mainstream. Misalnya, Zio yang lahir dengan tampang yang rupawan ini lebih senang berteman dengan perempuan dan melakukan segala aktivitas yang merujuk pada kebiasaan perempuan. Bahkan ia memiliki geng yang dinamakan Bebencongan dan di dalam geng itu ia diposisikan sebagai Queen $B$ atau ketua geng. Perilaku tokoh Zio ini tidak banyak mencerminkan sifat anak laki-laki pada umumnya yang macho dan tampil urakan.

Karakteristik tokoh Zio dalam novel The Name of The Game akan menjadi fokus utama dalam penelitian ini. Berkaitan dengan hal tersebut teori dan metode dekonstruksi dari Jaques Derida akan digunakan untuk mengupas karakteristik maskulinitas baru yang ditampilkan tokoh Zio. Dekonstruksi yang ditampilkan oleh Jaques Derida pada karya sastra tidak hanya memiliki satu pemikiran, namun sebuah karya sastra bisa saja memiliki makna ganda. Derida juga menuturkan dekonstruksi tidak hanya membahas cerita-cerita yang terpinggirkan, namun dekonstruksi menghadirkan sebuah konsep baru yang menggantikan konsep lama. Derida menolak ide makna tunggal yang absolut (the logos). Derrida menjelaskan bahwa logos tidak bisa tumbuh secara utuh, logos setidaknya membutuhkan sesuatu utnuk tumbuh karena logos tidak bisa hadir degan sendirinya (Al-Fayyadl, 2005:106-107).

Faruk (2017) menuturkan bahwasanya dekonstruksi adalah salah satu metode pembacaan teks yang dilakukan dengan cara cermat sehingga perbedaan-perbedaan konseptual yang dijadikan sebuah bagian dan merupakan dasar teks tersebut gagal berdasarkan tujuan yang inkonsisten dan paradoksikal dalam teks. Karya sastra dalam pandangan dekonstruksi selalu memiliki banyak arti, maka dari itu karya sastra dalam pandangan dekonstruksi akan menjadi sangat kompleks. Dekonstruksi itu memiliki sifat yang ambigu dan menentang adanya kemungkinan. Konsep dekonstruksi yang disuguhkan oleh Derida ini bisa diartikan mengangkat tentang permasalahn yang tidak diharapkan dalam karya sastra. Oleh karena itu terkadang hal tersebut menimbulkan keindahan bagi karya sastra.

Berdasarkan pemaparan yang telah dijelaskan, penelitian ini berfokus pada pembahasan mengenai dekonstruksi maskulinitas mainstream yang terjadi pada tokoh io dalam novel The Name of The Game karya Adelina ayu. Tujuan dari penelitan ini yakni untuk menguak wujud dekonstruksi maskulinitas mainstream pada tokoh Zio dalam novel The Name of The Game karya Adelina Ayu. Adapun manfaat dari penelitian ini adalah untuk menambah wawasan mengenai kajian tentang sastra populer dan dekonstruksi. Selain itu lewat penelitian ini diharapkan pula dapat membagi pengetahuan 


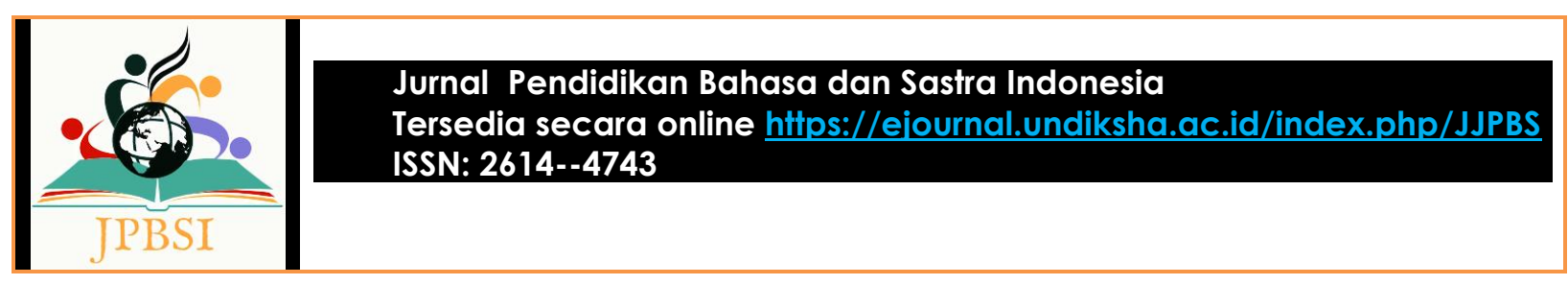

pada masyarakat umum mengenai dekonstruksi maskulinitas mainstream yang menghasilkan maskulinitas baru lewat tokoh Zio dalam novel The Name of The Game karya Adelina Ayu.

\section{METODE PENELITIAN}

Penelitian ini termasuk ke dalam penelitian kualitatif. Dalam penelitian kualitatif, data yang dihasilkan berupa data yang bersifat deskriptif (Lestari, 2017). Sumber data dari penelitian ini dibagi menjadi dua jenis. Jenis yang pertama adalah sumber data primer yang peneliti dapatkan dari novel The Name of The Game karya Adelina Ayu. Jenis sumber data yang kedua adalah sumber data sekunder yang didapatkan dari literatur-literatur lain seperti jurnal, buku teori, dan penelitian sejenis yang memiliki kaitan erat dengan penelitian ini.

Metode pengumpulan data yang digunakan dalam penelitian ini adalah metode membaca dan mencatat. Dalam teknik ini peneliti membaca terlebih dahulu keseluruhan novel, setelah itu peneliti memberikan tanda pada bagian-bagian yang berkaitan dengan dekonstruksi maskulinitas tokoh Zio, bagian yang ditandai selanjutnya dicatat dan diklasifikasikan untuk menyortir data yang relevan. Instrumen yang digunakan untuk membantu mengumpulkan data tersebut adalah tabulasi. Tabulasi ini digunakan untuk penyimpanan dan juga pengklasifikasian data. Teknik analisis data yang digunakan dalam penelitian ini merupakan teknik analisis isi yang akan membahas mengenai dokunstruksi maskulinitas mainstream dalam novel The Name of The Game karya Adelina Ayu.

\section{HASIL DAN PEMBAHASAN}

Dalam hasil dan pembahasan ini dijelaskan mengenai bentuk dekonstruksi maskulinitas mainstream yang terdapat di dalam novel The Name of The Game. Menurut Derida, salah satu ciri dari dekonstruksi adalah adanya wujud dari penolakan logosenetris dan fonosentris sehingga tumbuh oposisi biner dan tumbuhnya pemikiran yang baru. Oposisi biner ini berarti membandingkan dua objek, misalnya membandingkan sifat seseorang dengan orang lainnya. Dekonstruksi maskulinitas mainstream berarti membandingkan tokoh laki-laki satu dengan tokoh laki-laki yang lainnya dalam novel The Name of The Game. Peneliti akan memfokuskan pembahasan ini pada salah satu tokoh utamanya yakni Zio. Berikut ini merupakan dekonstruksi dari maskulinitas minstream yang ada di dalam novel The Name of The Game.

\section{Laki-Laki yang Merawat Diri}

David dan Brannon menyebutkan bahwasanya elemen pertama dalam maskulinitas yang harus dimiliki setiap laki-laki adalah No Sissy Stuff. Itu artinya laki-laki tidak boleh bersinggungan dengan hal-hal feminin yang biasanya dilakukan oleh para kaum perempuan. Berbicara masalah kegiatan-kegiatan yang berkaitan dengan perempuan, hal yang paling sering mereka lakukan adalah merawat dirinya. Perempuan sangat perduli dengan penampilan dirinya secara fisiologis. Dengan berbagai cara biasanya perempuan akan melakukan berbagai hal untuk mempercantik dirinya agar lebih percaya diri.

Sedangkan laki-laki pada umumnya lebih urakan. Kaum laki-laki biasanya tidak terlalu memperhatikan perawatan tubuhnya secara detail. Misalnya dari cara berpakaian yang monoton. Di dalam novel The Name of The Game contoh itu bisa kita lihat lewat tokoh Daryll misalnya. Daryll diceritakan sering mengenakan kemeja flanel dengan celana jeans yang lusuh. Ia juga kerap kali diceritakan menggunakan sepatu convers belel dengan jam tangan $G$-Shock hitam yang tak pernah ganti. Daryll tidak pernah mengenakan riasan wajah atau bahkan skin care untuk melindungi dan mempertampan diri. Melihat perilaku Daryll, bisa dikatakan bahwa Daryll merupakan contoh laki-laki pada umumnya yang terpaku pada maskulinitas mainstream yang tidak bersinggungan dengan hal-hal yang feminin seperti halnya merawat diri.

Berbeda dengan tokoh Daryll, Zio menghadirkan sebuah maskulinitas yang baru. Ia menunjukkan diri sebagai laki-laki yang perduli dengan penampilan. Zio kerap kali diceritakan 


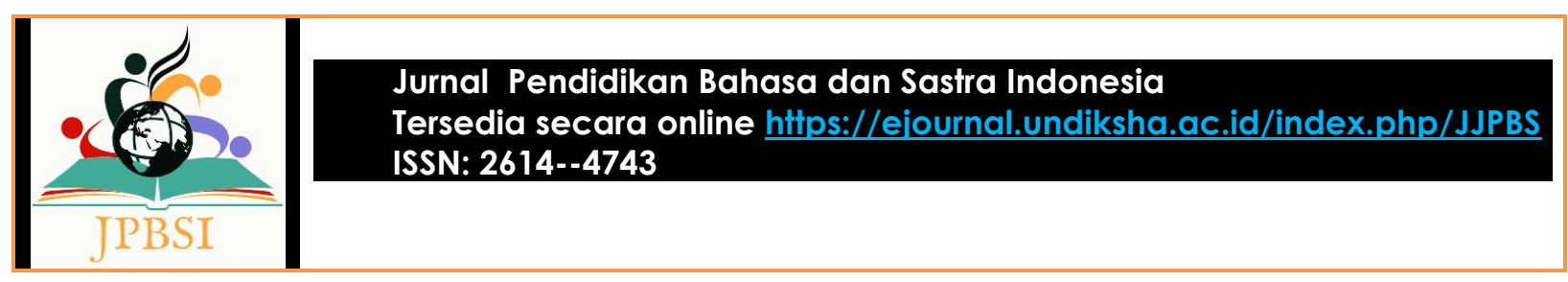

mengenakan pakaian yang berbeda-beda setiap pergi ke kampus. Zio lebih stylish dan pintar memadupadankan apa yang ia kenakan. Selain berpakaian modis, Zio juga selalu menjaga wajahnya. Ia diceritakan sering menggunakan skincare bahkan ia memiliki rutinitas tersendiri untuk menjaga kulitnya setiap malam. Selain itu Zio juga sering pergi berbelanja ke toko make-up, contohnya seperti dalam kutipan berikut ini.

"Kok Bercanda? Ngapain juga gue bercanda? Emag gue mau ke Sephora kok. Banyak yang pingin gue beli." Kata cowok itu santai sambil mengambil keranjang warna hitam Sephora.

(TnoTG, Hlm. 103)

Zio menggunakan beberapa peralatan make-up. Yang selalu ia bawa setiap hari di dalam tasnya adalah lipbalm dan pelembab. Lipbalm ia gunakan untuk mengatasi bibirnya yang sering kering dan berdarah. Pelembab ia gunakan untuk melindungi kulitnya dari terik matahari. Selain kedua item itu, Zio juga sering membawa obat tetes mata untuk membasahi softlens matanya. Zio adalah pria yang tidak takut dengan gunjingan orang lain. Zio memiliki pandangan bahwa laki-laki juga harus menjaga dan merawat penampilannya. Hal bertolak belakang dengan maskulinitas mainstream dan menciptakan maskulinitas baru yang tentu saja menguntungkan bagi laki-laki.

\section{Bebas Mengekspresikan Diri}

Dalam budaya Indonesia, laki-laki selalu dituntut untuk menjadi pribadi yang kuat. Lelaki dilarang untuk menunjukkan kesedihannya. Kentalnya heteronormativitas dalam budaya Indonesia terkadang memang mengekang kaum laki-laki untuk mengekspresikan dirinya. Karena tuntutan laki-laki harus kuat, maka mereka dilarang menunjukkan kelemahannya. Bahkan tidak jarang juga laki-laki dianggap tidak normal ketika mereka mengekspresikan kebahagian yang berlebihan. Seperti dalam kutipan di bawah ini.

"Lo liat aja kelakuan cowok itu kaya gimana, udah ngejelasin semuanya, kok." Dello mengangkat bahu, merasa sudah menang. "Ketawa-ketiwinya aja melengking, gerakannya melambai, terus lo liat aja tuh badannya. Pasti dribble bola aja nggak bisa." (TnoTG, hlm. 304)

Terlihat dalam kutipan tersebut bahwasanya anak laki-laki akan dianggap aneh dan tidak normal apabila mengekspresikan dirinya terlalu berlebihan. Mereka dianggap sebagai produk yang gagal di masyarakat bahkan kerap mendapatkan cibiran kurang baik dari orang lain.

Berbeda dengan kebanyakan laki-laki yang menampilkan dirinya sebagai pribadi yang kuat dan kaku, Zio malah mengekspresikan dirinya secara bebas. Ia dengan senang hati menampilkan siapa dirinya tanpa harus malu ataupun takut dianggap sebagai laki-laki yang 'gagal' di dalam masyarakat. Ia sering mengekspresikan kebahagiannya dengan teman-temannya. Zio senang sekali bergosip dan diceritakan bahwa ia sering mencari informasi gosip di akun lambe turah untuk diceritakan bersama teman-teman perempuannya. Zio juga memiliki julukan Queen $B$ di dalam grupnya karena ia sering memimpin teman-teman perempuannya dalam segala hal. Zio tidak takut menunjukkan kesedihannya bahkan ketakutannya sekalipun. Ia dengan terang-terangan bercerita mengenai kelemahannya pada tokoh Flo, Flo adalah wanita yang ia cintai. Biasanya para lelaki akan menyembunyikan kelemahannya di hadapan wanita idamannya. Tetapi Zio dengan santai menunjukkan kelemahan yang dia miliki tanpa ada rasa takut sama sekali.

Yang paling unik dari tokoh Zio adalah dia sering mengekspresikan apa yang ada di dalam pikirannya dengan bahasa-bahasa yang sering digunakan oleh para transgender ibu kota. Zio menggunakan kode bahasa ini untuk mengekspresikan perasaannya kepada teman-temannya. Seperti halnya contoh pada kutipan di bawah ini.

"Emang dari awal nggak ada. Lo nya aja yang ngotot masih ngarep sama dia. Bikin khawatir aja sih. Kalo jedong pewong indang reus pinter. Jengong jedong bego gargalita lekonggg shay. 


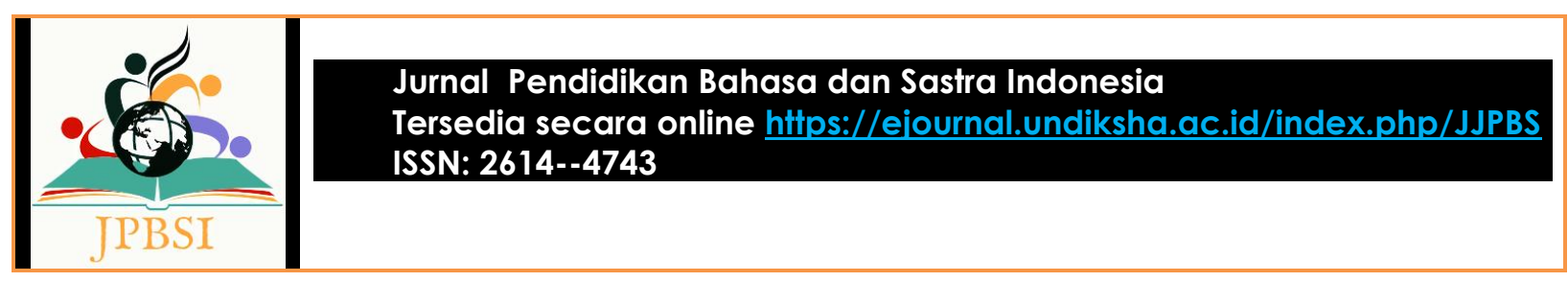

Kasino kepala yeti kelong galau gargalita lekong. Semuweus faktamorgana kalalo Daryll tintus sukiyaki yeti udin adindut di depan mataram tapioka yeti ajijut yang masionil nguotot." (TNoTG, Hlm. 281).

Kutipan tersebut terjadi saat Zio dan Flo berdioalog mengenai kejadian penolakan cinta Flo oleh Daryll. Zio meluapkan kekesalannya dengan menggunakan kode bahasa yang biasanya digunakan oleh para transgender ibu kota. Selain di percakapan itu, Zio juga menggunakan kode bahasa transgender ini di beberapa bagian lain di dalam cerita. Tanpa ragu ia mengucapkannya seperti layaknya bahasa yang memang ia gunakan dalam kesehariannya. Jika dilihat dari sudut pandang heteronormativitas budaya kita, Zio memang sangat jauh berbeda dengan laki-laki yang menampilkan diri dengan maskulinitas mainstream. Namun tanpa disadari, Zio menunjukkan tatanan maskulinitas baru yang membebaskan laki-laki untuk mengekspresikan dirinya baik dalam keadaan senang maupun sedih. Zio adalah laki-laki yang berani mendobrak stereotipe masyarakat tentang ketangguhan dan kekakuan seorang laki-laki dan dia juga dengan percaya diri menampilkan diri sebagaimana adanya tanpa harus menyembunyikan kelemahannya pada orang lain.

\section{Lelaki Yang Lemah Lembut}

David dan Brannon menyebutkan dalam teori maskulinitasnya bahwa laki-laki haruslah memiliki keberanian dan agresi serta harus mengambil resiko meskipun takut untuk melakukannya. Laki-laki dianggap sebagai pribadi yang harus menempuh jalan hidupnya dengan kekerasan tanpa ada belas kasih. Hal-hal yang seperti itu tidak berlaku di dalam kehidupan tokoh Zio. Zio adalah seorang laki-laki yang sering menghindari pertikaian. Zio bukan tipe laki-laki yang agresif dan senang menantang untuk membuat keributan. Zio menciptakan citra seorang laki-laki yang lemah lembut dan cinta damai. Perilakunya yang tidak memunculkan sisi maskulin membuat ia sering mendapatkan perundungan oleh orang-orang sekitarnya. Terkadang Zio sering terganggu dan membalas cibiran itu dengan emosi, namun ia lebih sering menghadapinya dengan kesabaran. Misalnya saja ketika ia dibanding-bandingkan dengan tokoh Daryll seperti dalam kutipan di bawah ini.

Nggak Cuma sekali gue mendengar cewek-cewek itu bilang "Zio ganteng, tapi gue lebih suka Daryll", "Daryll atau Zio? Daryll lah. Zio mah enakan dijadiin temen aja", "Kalau sama Zio nanti kalah cantik dong hahahahaha Mending Daryll kemana-mana" (TnoTG, Hlm. 93)

Mendengar cibiran dari teman perempuannya seperti itu, Zio tidak melawan sedikitpun. Ia membiarkannya begitu saja. Di satu sisi memang Zio terlihat lemah karena ia membiarkan orang lain menginjak-injak harga dirinya. Namun di sisi yang lain, Zio adalah orang yang menang. Menang dalam menahan amarahnya agar ia tidak melawan seorang perempuan. Memang ada kalanya ia juga melawan cibiran itu dengan kekerasan, seperti halnya pada saat ia mengikuti pertandingan basket dengan mahasiswa Teknik Mesin. Zio yang mendapat cibiran dari teman satu timnya segera menerjang dan berkelahi di lapangan basket. Ia sulit menahan amarahnya karena ia dipermalukan dan difitnah menyukai sesama jenis di hadapan semua orang. Hal lain yang menunjukkan bahwa Zio adalah pria yang lemah-lembut, bisa dilihat dari caranya berkomunikasi dengan Flo. Zio sangat menghargai Flo sebagai seorang perempuan. Ia memperlakukan Flo sebaik mungkin. Kedekatan Zio bersama bundanya juga menunjukkan bahwa ia adalah anak yang sangat menyayangi ibunya.

Berdasarkan ketiga hal yang telah dijelaskan tersebut, dapat kita pahami bahwa tokoh Zio menghadirkan maskulinitas yang baru. Dekonstruksi yang terjadi pada maskulinitas mainstream mewujudkan maskulinitas yang unik. Maskulinitas yang ditampilkan oleh Zio dalam novel The Name of The Game ini juga merujuk pada perilaku metroseksual. Istilah mengenai pria metroseksual ini pertama kali muncul dalam surat kabar Independent di tahun 1994. Mulyana (2014) menjelaskan bahwa secara etimologis metroseksual ini berasal dari kata metropolis dan seksual. Jadi metroseksual ini merujuk pada sosok laki-laki yang narsistik dengan penampilan "dendi" yang jatuh cinta tidak hanya 


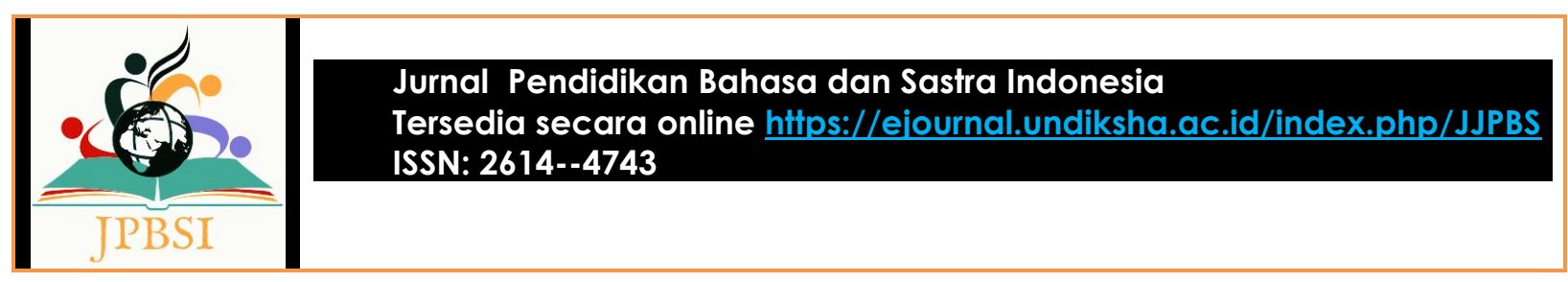

pada dirinya sendiri, tetapi juga gaya hidup urban. Laki-laki metroseksual seperti Zio ini memang cenderung narsis dan tidak malu-malu menunjukkan sisi feminin dari dirinya.

Pria Metroseksual biasanya memiliki motivasi untuk terlihat berbeda dibandingkan dengan pria-pria pada umumnya. Mereka akan melakukan berbagai cara untuk mendapatkan perhtian dari lingkungan terdekat juga dari orang lain khusunya lawan jenis (Triswidiastuty \& Kahija, 2015: 62). Hal itu terlihat sangat jelas dalam tokoh Zio. Ia merawat diri dan berpenampilan fashinable bertujuan untuk memikat lawan jenisnya seperti tokoh Flo. Pada akhirnya ia mendapatkan apa yang ia mau karena tokoh Flo memilih dirinya daripada Daryll yang berpenampilan urakan. Perilaku Metroseksual yang ditampilkan oleh tokoh Zio ini bisa dikatakan menjadi maskulinitas baru di masa kini. Untuk sebagian tokoh, maskulinitas yang ditampilkan oleh Zio ini belum bisa diterima. Tokoh-tokoh yang tidak bisa menerima kehadiran maskulinitas baru yang ditampilkan oleh Zio ini dipengaruhi oleh budaya heteronormativitas yang mereka anut dan maskulinitas mainstream yang telah melekat di dalam dirinya masing-masing. Namun ada pula tokoh-tokoh yang menyadari tentang hadirnya bentuk maskulinitas baru ini dan memberikan respon yang baik. Contohnya seperti tokoh Daryll dan Iyen. Kedua pria itu menyambut hal-hal positif dalam maskulinitas baru yang ditampilkan oleh Zio. Mereka menganggap bahwa maskulinitas baru ini membuat laki-laki terbebas dari tuntutan-tuntutan masyarakat yang mengekang keinginan mereka.

\section{PENUTUP}

Pada dasarnya gender merupakan sesuatu hal yang cair dan bisa dipertukarkan. Hal ini disebabkan karena gender bukanlah sesuatu hal yang bersifat kodrati. Maskulinitas tidak selamanya harus terpaku pada dunia laki-laki. Jika mengacu pada konsep gender, maka laki-laki pada dasarnya bisa menampilkan sifat feminin di dalam dirinya. Seperti halnya yang dilakukan oleh tokoh Zio dalam novel The Name of The Game. Zio berhasil mengubah paradigma orang-orang di lingkungan sekitarnya mengenai maskulinitas mainstream yang biasanya ada di dalam diri laki-laki. Zio tanpa disadari mendekonstruksi maskulinitas mainstream tersebut dengan menghadirkan maskulinitas yang baru. Senang merawat diri, bebeas mengekpresikan diri, dan berperilaku lemah lembut adalah tiga aspek yang Zio tampilkan dalam dirinya. Ia mematahkan konsep maskulinitas mainstream yang dianggap mengekang pria untuk bebas berekspresi. Ketiga aspek maskulinitas baru yang dihadirkan oleh Zio ini merujuk pada perilaku metroseksual yang pada saat ini banyak dilakukan oleh laki-laki modern. Hal ini menunjukkan bahwa adanya era baru dalam memandang maskulinitas laki-laki di dalam masyarakat. Pada intinya, merawat diri, bebas berekspresi, dan kelemahlembutan yang dibawakan Zio lewat pribadinya menciptakan maskulinitas baru pada diri seorang laki-laki. Maskulinitas baru ini memadupadankan antara sifat maskulin dan feminin yang seimbang. Lewat kepribadiannya yang unik, Zio menunjukkan bahwasanya laki-laki tidak harus selalu kaku, urakan, dan agresif. Namun laki-laki juga bisa tampil lebih modis, ekspresif, dan penuh kasih sayang saat berinteraksi dengan orang-orang di sekitarnya.

\section{DAFTAR PUSTAKA}

Al-Fayyadl, M. (2005). Derrida. Yogyakarta: LKIS Pelangi Aksara.

Ayu, A. (2019). The Name of The Game. Jakarta: PT Gramedia Pustaka Utama

Barlas, A. (2007). Cara Quran Membebaskan Perempuan. Jakarta: Serambi.

David, D., \& Brannon, R. (1976). The Forty Nine Percent Majority: The Male Sex Role. New York: Random House.

Dermatoto, A. (2010). Konsep Maskulinitas dari Zaman ke Zaman dan Citranya dalam Media. Jurnal Jurusan Sosiologi Fakultas Ilmu Sosial Dan Politik UNS Surakarta.

Faruk. (2017). Metode Penelitian Sastra. Yogyakarta: Pustaka Pelajar.

Lestari, E. (2017). Representasi Multikultural Dalam Novel Burung-Burung Rantau Karya Y.B Mangunwijaya Sebagai Sarana Pendidikan Karakter Bangsa Berbasis Budaya Siswa SMA. 


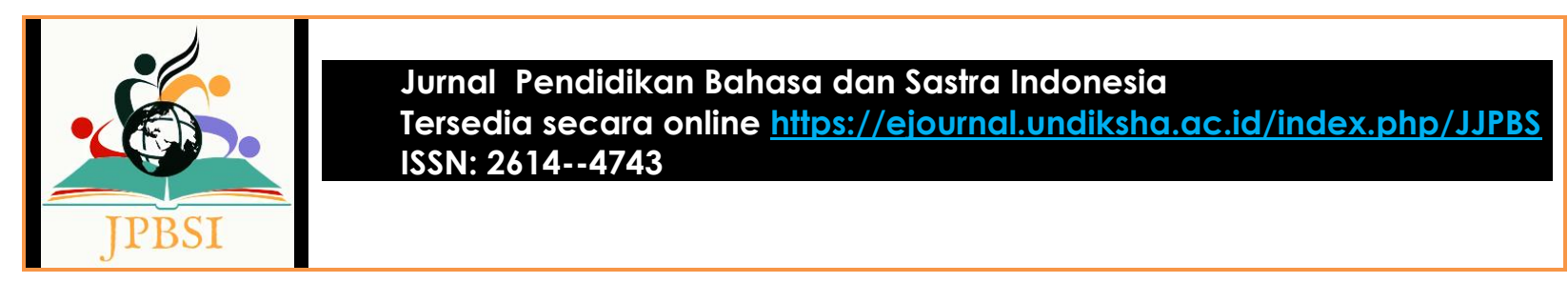

Prosiding SENASGABUD, 53-63.

Mulyana, A. (2014). Representasi Gaya Hidup Pria Metroseksual di MajalahIbu Kota. Jurnal Visi Komunikasi, 13, 69-86.

Prameswari, N. S. (2014a). Di Balik Topeng Maskulinitas Iklan Rokok: Kritik TErhadap Iklan Rokok A Mild Media Outdoor Versi Berani Takut. Imaji, 12, 39-54.

Prameswari, N. S. (2014b). Komodifikasi Maskulinitas Dan REalitas: Iklan Rokok Bintang Buana Filter. Creativitas, 3, 91-108.

Pratami, R., \& Hasiholan, T. P. (2020). Representasi Maskulinitas Oria dalam Iklan Televisi Men's Biore Cool Oil Clear. Jurnal Komunikasi, 14, 119-138.

Triswidiastuty, S., \& Kahija, Y. F. La. (2015). Memahami Makna Menjadi Pria Metroseksual. Jurnal Empati, 4, 58-64.

Copyright holder: @ Alamsyah, Z., Adji M. \& Hidayatullah, M. I. (2021)

Fist publication right: Jurnal Pendidikan Bahasa dan Sastra Indonesia Undiksha 